STUDIA HISTORICA GEDANENSIA

TOM X (2019)

Maciej Fic

(Instytut Historii, Uniwersytet Śląski)

\title{
Pół wieku edukacji historycznej na Uniwersytecie Śląskim w Katowicach. Z dziejów Instytutu Historii UŚ (1969-2019)
}

\section{Zanim powstał Uniwersytet Śląski}

Instytut Historii [IH] pozostaje jedną z najstarszych jednostek współtworzących dziś Uniwersytet Śląski, ale geneza instytucjonalnej działalności górnośląskich historyków sięga jeszcze rzeczywistości sprzed powstania tej Uczelni. Oferta studiów historycznych (co prawda w pierwszej kolejności prowadzonych w trybie zaocznym dla osób pracujących) pojawiła się w roku akademickim 1957/1958, w ramach istniejącej od 1950 r. w Katowicach Wyższej Szkoły Pedagogicznej [WSP]. Powstał wówczas Wydział Filologiczno-Historyczny [WF-H], w ramach którego utworzono Katedrę Historii ${ }^{1}$. To właśnie w tej placówce należy widzieć jednego z protoplastów dzisiejszego IH Uniwersytetu Śląskiego. Pierwszym kierownikiem Katedry został badacz historii Śląska i absolwent Uniwersytetu Jagiellońskiego [UJ] Kazimierz Popiołek, w tym okresie związany ze Śląskim Instytutem Naukowym [ŚIN] w Katowicach, który opracował pięcioletni program studiów historycznych ${ }^{2}$. Dużą część programu zajmowały treści związane z archeologią i historią średniowieczną, można też było dostrzec pierwsze symptomy badań regionalnych (zwłaszcza poprzez dobór tematyki prac magisterskich). Początkowo studia historyczne prowadziło zaledwie kilkoro pracowników, m.in. uznany już wówczas badacz starożytności Józef Wolski, specjalizujący się w historii wojskowości inny wychowanek UJ Jan Pachoński, związana najpierw z Uniwersytetem im. Jana Kazimierza we Lwowie, a następnie z UJ mediewistka Julia Radziszewska

1 „Wyrósł z dobrego drzewa”. Uniwersytet Śląski 1968-1998. Fakty, dokumenty, relacje, red. Antoni Barciak (Katowice: Wydawnictwo Uniwersytetu Śląskiego: 1998), 228-229.

2 Maciej Fic, Między nauka a propagandą. Śląski Instytut Naukowy im. Jacka Koraszewskiego w Katowicach (1957-1992) (Katowice: Wydawnictwo Uniwersytetu Śląskiego, 2014), 138. 
oraz wspomniany już Popiołek. Do prowadzenia zajęć zatrudniano także „miejscowych" historyków, np. dyrektora Wojewódzkiego Archiwum Państwowego w Katowicach Michała Antonowa ${ }^{3}$.

Początek lat sześćdziesiątych XX w. przyniósł dalszy rozwój Katedry Historii WSP, którą od 1963 r. kierował Pachoński. W 1965 r. na kierunku historycznym rozpoczęło działalność Studium Zaoczne dla absolwentów studiów nauczycielskich, przygotowujące do nauczania historii tę grupę zawodową.

\section{W realiach PRL (w latach 1968-1989)}

W 1968 r. jako dziewiąty uniwersytet w Polsce i pierwszy powołany do życia w realiach Polskiej Rzeczypospolitej Ludowej swoją działalność rozpoczął Uniwersytet Śląski w Katowicach ${ }^{4}$. Inauguracja pierwszego roku akademickiego miała miejsce 1 października 1968 r. Rektorem nowo powołanego uniwersytetu został Popiołek. Historia stała się jednym z kierunków studiów, które można było studiować w ramach utworzonego wraz z uniwersytetem w 1968 r. Wydziału Humanistycznego ${ }^{5}$. Przez okres jednego roku akademickiego (1968/1969) historycy prowadzili swoją działalność w ramach Zespołowej Katedry Historii, a po wprowadzeniu w życie nowej organizacji uczelni wyższych (26 czerwca 1969 r.), w ramach IH. Katedra Historii w pierwszym okresie była niewielką jednostką organizacyjną, której kadra naukowo-dydaktyczna wywodziła się głównie z ośrodków współtworzących UŚ. Jej pierwszymi etatowymi pracownikami byli: Popiołek (jednocześnie pierwszy dyrektor IH), Pachoński, Wanda Zarembina, Radziszewska, Alfons Mrowiec, Kazimierz Sarna, Mieczysław Grzyb, Tadeusz Żerdziński oraz Tadeusz Kaszper. Podobnie jak w przypadku Katedry Historii WSP pracę etatowych uczonych uzupełniano przy pomocy grupy 21 osób zatrudnionych na podstawie

3 Por. Wyższa Szkoła Pedagogiczna w Katowicach 1950-1968, red. Adam Jarosz, Augustyn Jendrysik (Katowice: Wydawnictwo Uniwersytetu Śląskiego, 1971); Tadeusz Aleksandrowicz, „Kształtowanie się i rozwój katowickich ośrodków badań nad kulturą antyczną", w Katowice w 145. rocznicę uzyskania praw miejskich. Katowice w kulturze pamięci, red. Barciak (Katowice: Polska Akademia Nauk Oddział w Katowicach, 2011), 257; Wacław Gojniczek, Barbara Kalinowska-Wójcik, „Z dziejów nauczania archiwistyki na Uniwersytecie Śląskim. W trzydziestą rocznicę uruchomienia specjalności archiwalnej”, Res Historica 28 (2009): 163.

4 Por. Zarządzenie Ministra Oświaty i Szkolnictwa Wyższego w sprawie organizacji Uniwersytetu Śląskiego w Katowicach. „Dziennik Urzędowy Ministerstwa Oświaty i Szkolnictwa Wyższego” 1968, nr A-10, poz. 71; Henryk Rechowicz, „W służbie nauki i regionu”, w 10 lat Uniwersytetu Ślaskiego 1968-1978, red. Jan Kantyka (Katowice: Wydawnictwo Uniwersytetu Śląskiego, 1978), 31; Maciej Salamon, „Powstanie Uniwersytetu Śląskiego,” w Katowice w 143. rocznicę uzyskania praw miejskich. W 40-lecie powstania Uniwersytetu Ślaskiego - szkolnictwo i nauka na Górnym Ślasku, red. Barciak (Katowice: Polska Akademia Nauk Oddział w Katowicach, 2009), 54.

5 Por. Inauguracja I roku akademickiego Uniwersytetu Ślaskiego w Katowicach, red. Michał Staszków (Wrocław: Zakład Narodowy im. Ossolińskich, 1969), 9. 
umowy-zlecenia. W najwcześniejszym okresie istnienia Instytut mieścił się w kilku pokojach w budynku obecnego Śląskiego Wyższego Seminarium Duchownego przy ulicy Wita Stwosza 17a w Katowicach ${ }^{6}$.

Podjęte starania, którym patronował rektor Popiołek, pozwoliły na rozbudowę organizacyjną i naukową jednostki. Osiągnięty stan kadrowy (dzięki pozyskaniu nowych uczonych) umożliwił utworzenie w ramach IH początkowo dwóch zakładów: Historii Starożytnej i Średniowiecznej (kierował nim przybyły z Uniwersytetu Łódzkiego znawca epoki Jagiellonów Stefan Maria Kuczyński) oraz Historii Nowożytnej i Najnowszej (na czele stanął Pachoński). Z powodu szczupłości kadr w najwcześniejszym okresie istnienia UŚ funkcjonowały jedynie (podobnie jak wcześniej w przypadku WSP) wieczorowe studia historyczne dla pracujących, studenci studiów stacjonarnych rozpoczęli studia w $1969 \mathrm{r}^{7}$ Pierwsza grupa 37 absolwentów IH UŚ opuściła mury uczelni w 1974 r. w strukturze nowo powstałego w 1973 r. Wydziału Nauk Społecznych.

Początek dekady lat siedemdziesiątych XX w. stanowił okres, w którym dzięki wsparciu wojewódzkich władz partyjno-państwowych w IH zatrudniono kolejnych naukowców. Część z nich (jak np. specjalista z zakresu nauk pomocniczych historii Józef Szymański, badacz zajmujący się historią gospodarczą i historia Śląska w XIX w. Wacław Długoborski czy historyk badający dzieje Śląska w XX w. i drugi dyrektor Instytutu Henryk Zieliński) opuściła mury IH UŚ stosunkowo szybko, ale wielu innych (m.in. historyk starożytności na ziemiach polskich Jerzy Szydłowski, historyk Europy Środkowo-Wschodniej Józef Chlebowczyk, historyk starożytności Andrzej Kunisz czy historyk Śląska i Zagłębia Dąbrowskiego w XX w. Henryk Rechowicz) na długie lata związało się z katowickim ośrodkiem. W grupie pierwszych asystentów IH znaleźli się przede wszystkim młodzi wówczas absolwenci historii (głównie z UJ): Antoni Barciak, Janusz Gruchała, Anna Krupska, Maria Kwaśny, Barbara Trelińska, Maciej Salamon i Urszula Zgorzelska. Także w tym przypadku jedni po kilku latach zmienili miejsce zatrudnienia (np. bizantynista Salamon związał się z UJ, Trelińska z Uniwersytetem im. M. Skłodowskiej-Curie w Lublinie), inni (jak Barciak, Gruchała i Krupska) przez całą swoją drogę zawodową pozostali związani z IH UŚ

6 Andrzej Topol, Kazimierz Popiołek i jego czasy (1903-1986) (Katowice-Warszawa: „Śląsk” Wydawnictwo Naukowe, 2004), 84.

Warto odnotować, że od samego początku istnienia IH UŚ rozpoczęło przy nim swoją działalność Studenckie Koło Naukowe Historyków. Szerzej: 35 lat Studenckiego Koła Naukowego Historyków, red. Izabela Lar (Katowice: Studenckie Koło Naukowe Historyków, Instytut Historii, Uniwersytet Śląski, 2004).

8 Topol, Kazimierz Popiołek i jego czasy, 85. Por. Krzysztof Nowak, „Janusz Gruchała (24 VIII 1949-21 XI 2011)”, Studia z Dziejów Rosji i Europy Środkowo-Wschodniej 47 (2012), 400; Wiesław Kaczanowicz, „Profesor dr hab. Andrzej Kunisz (1932-1998)”, w Studia z dziejów antyku. Pamięci Profesora Andrzeja Kunisza, red. Wiesław Kaczanowicz (Katowice: Wydawnictwo Uniwersytetu Śląskiego, 2004), 7-13; Tadeusz Aleksandrowicz: „Kształtowanie się i rozwój”, 257-259; idem, „Profesor Andrzej Kunisz - założyciel pierwszego na Górnym Śląsku ośrodka badań nad antykiem”, 
Od samego początku z oczywistych powodów funkcjonowanie Instytutu mogło liczyć na zrozumienie i wsparcie ze strony władz rektorskich. Nie inaczej było po zmianie na stanowisku retora UŚ, która nastąpiła w 1972 r. Następcą Popiołka został bowiem kolejny historyk, Rechowicz. Prowadzone przezeń działania, oparte o głoszoną ideę rozwoju humanistyki (tłumaczoną „potrzebą humanizacji środowiska") pozwoliły na systematyczne wzmacnianie potencjału IH. Po okresie, gdy lokalizacja IH znajdowała się w budynku przy ulicy Wita Stwosza 17/17a, od roku akademickiego 1978/1979 jego siedzibę przeniesiono do nowo wybudowanego gmachu na ul. Bankowej 11 (budynek ten pozostaje siedzibą IH do chwili obecnej) ${ }^{9}$.

W dekadzie lat siedemdziesiątych IH wzmocnił i ustabilizował swoją pozycję. Kadra składała się z naukowców pochodzących z różnych środowisk: obok pracowników związanych uprzednio z UJ (Pachoński, Radziszewska, badacz nowożytności Henryk Kocój) byli to historycy (głównie badacze XIX i XX w.) wcześniej pracujący w ŚIN (m.in. Chlebowczyk, Jan Kantyka, Eugeniusz Kopeć, Marek Paździora, Rechowicz, Franciszek Serafin, Andrzej Topol, Jan Walczak, Maria W. Wanatowicz), uczeni związani z placówkami naukowymi Wrocławia (nowożytnik Michał Komaszyński, badacze wieków XIX i XX Długoborski i Stanisław Michalkiewicz), absolwent Katolickiego Uniwersytetu Lubelskiego i specjalista z zakresu nauk pomocniczych historii Szymański czy wcześniej zatrudniony w Wojewódzkim Archiwum Państwowym w Katowicach, badacz historii przemysłu Jerzy Jaros ${ }^{10}$. Obecna w realiach PRL kontrola i nadzór władz partyjno-państwowych nad procesem kształcenia i badań naukowych w IH UŚ

w Śląscy uczeni. O tych, co odeszli, red. Jan Malicki, Józef Śliwiok, Magdalena Skóra (Katowice: Biblioteka Śląska w Katowicach, Górnośląskie Towarzystwo Przyjaciół Nauk im. Walentego Roździeńskiego w Katowicach, 2007), 215-227; „Non omnis moriar”. Zmarli Pracownicy Uniwersytetu Ślaskiego w Katowicach 1968-2008, red. Barciak (Katowice: Wydawnictwo Uniwersytetu Śląskiego, 2008), 198; Profesor Jerzy Szydłowski. Wspomnienie o Mistrzu, red. Beata Badura (Bytom: Muzeum Górnośląskie, 2017).

9 Por. Fic, „Henryk Rechowicz i jego wpływ na kształtowanie się środowiska naukowego Katowic", w Póltora wieku dziejów Katowic. Przywracanie historycznej pamięci, red. Barciak (Katowice: Muzeum Historii Katowic, 2016), 273-283; idem, „»Wielki wybitny historyk śląski«. Biografia prof. Henryka Rechowicza jako przykład kariery naukowej w Polskiej Rzeczypospolitej Ludowej”, w In servitute scientiarum. Biografistyka - Galicja - Druga Rzeczpospolita. Ksiega pamiątkowa w 10. rocznicę śmierci Profesora Leszka Kuberskiego, red. Antoni Maziarz (Opole: Wydawnictwo Uniwersytetu Opolskiego, 2017), 213-214.

10 Por. tenże: „Między nauką a propagandą”, 275; idem, „»Każdy z nas kiedyś miał swego Mistrza...«. Pamięci Profesora Franciszka Serafina”, w Z tęsknoty za Mistrzem, red. Jacek Kurek, Krzysztof Maliszewski (Chorzów: Miejski Dom Kultury „Batory” 2007), 87-92; Nowak, „Życiorys Profesora”, w Józef Chlebowczyk - badacz procesów narodowotwórczych w Europie XIX i XX wieku, red. Maria W. Wanatowicz (Katowice: Wydawnictwo Uniwersytetu Śląskiego, 2007), 7-11; Teresa Roszkowska, „Wspomnienie o Mistrzu”, Zaranie Śląskie. Seria Druga 1 (2015), 80-81; Tomasz Hajewski, „Przemiany organizacyjne Archiwum Państwowego w Katowicach (1945-2012)", w Archiwum w regionie. Region w archiwum. 80 lat Archiwum Państwowego w Katowicach 1932-2012, red. Kalinowska-Wójcik (Katowice: Archiwum Państwowe w Katowicach, 2012), 60; Aleksandra Skrzypietz, „Michał Komaszyński (23 II 1924-12 XII 2007)”, Kwartalnik Historyczny 2 (2008), 178-181; Gojniczek, Kalinowska-Wójcik, „Z dziejów nauczania archiwistyki”, 164. 
wpłynęły także na zatrudnienie w jego strukturach grupy historyków-marksistów, wśród których niewątpliwie najważniejszymi postaciami (obok Rechowicza) byli: Jarema Maciszewski (późniejszy kierownik Wydziału Nauki i Oświaty KC PZPR) i Andrzej Werblan (dyrektor Instytutu Podstawowych Problemów Marksizmu i Leninizmu KC PZPR i przez wiele lat główny ideolog partii) ${ }^{11}$. Wśród wykładowców w latach siedemdziesiątych ubiegłego stulecia pojawili się także pierwsi absolwenci IH UŚ, by wymienić tylko związanych z IH przez kolejne dekady: badaczy starożytności Wiesława Kaczanowicza i Norberta Rogosza, historyka oświaty i dydaktyki historii Annę Glimos-Nadgórską i historyka XX w. Sylwestra Fertacza. Przypadająca na lata siedemdziesiąte XX w. rozbudowa IH przejawiała się także w rozszerzeniu struktury organizacyjnej (pojawiały się kolejne zakłady) i oferowanych specjalności studiów (najliczniej wybieranymi były: archiwalna i nauczycielska). Pracownicy IH skupieni zostali w sześciu zakładach: Historii Starożytnej i Średniowiecznej; Historii Nowożytnej; Historii XX wieku; Historii Najnowszej; Metod Badań Historycznych i Nauk Pomocniczych oraz Metodologii Historii ${ }^{12}$.

Zmiany dekady lat siedemdziesiątych ubiegłego wieku wiązały się także ze zwiększeniem nacisku na badania nad historią XX w. (zwłaszcza „historią ruchu robotniczego"). Wszystkie te działania wpłynęły na powolny wzrost znaczenia IH UŚ w skali kraju. Instytut Historii Uniwersytetu Śląskiego coraz częściej bywał organizatorem ważnych środowiskowych spotkań (np. poświęconej naukom pomocniczym historii konferencji w maju $1972 \mathrm{r}^{13}$ ). Najbardziej wymiernym dowodem znaczenia górnośląskiego środowiska historycznego było jednak przyznanie mu organizacji XII Powszechnego Zjazdu Historyków Polskich (17-20 września 1979 r.) - pierwszego w historii tego typu zjazdu, który miał miejsce na Górnym Śląsku ${ }^{14}$. Coraz częściej pracownicy IH wchodzili w skład różnych ogólnopolskich gremiów, np. Michalkiewicz był członkiem Zespołu Dydaktyki i Wychowania przy Ministrze Nauki, Szkolnictwa Wyższego i Techniki, a Chlebowczyk wiceprezesem Zarządu Głównego PTH. Pracownicy Instytutu kierowali także uczelnianymi instytucjami, np. Antoni Molenda stał na czele Biblioteki Głównej UŚ, Pachoński kierował Studium Języków Obcych US ${ }^{15}$. W dekadzie lat siedemdziesiątych

11 Por. Informator dla przemysłu, red. Halina Słaby (Katowice: Wydawnictwo Uniwersytetu Śląskiego, 1973), 44-45; Czesław Nowarski, Akademickie kształcenie nauczycieli historii w Polsce (1945-1980) (Kraków: Wydawnictwo Naukowe Akademii Pedagogicznej w Krakowie, 1999), 404.

12 Por. ibidem, 390; Gojniczek, Kalinowska-Wójcik, „Z dziejów nauczania archiwistyki”, 165; Anna Glimos-Nadgórska, „Szkoły i nauczyciele - opiekunowie studenckich praktyk ciągłych”, w Praktyczne kształcenie kandydatów na nauczycieli historii, red. Janina Mazur, Alojzy Zielecki (Rzeszów: Libri Ressovienses, 1998), 131.

13 Roszkowska, „Wspomnienie o Mistrzu”, 81.

14 Zygmunt Woźniczka, „Historia Uniwersytetu Śląskiego do 1983 roku”, w „Mądrość zbudowała sobie dom...”. Uniwersytet Śląski 1968-2008. Dzieje, dokumentacja, źródła, red. Barciak (Katowice: Wydawnictwo Uniwersytetu Śląskiego, 2008), 96.

15 Protokół z posiedzenia Senatu UŚ, 19 IX 1980; Archiwum Uniwersytetu Śląskiego w Katowicach (AUŚ), Protokoły Senatu UŚ 1980, 139/5, k. 12; Lista obecności z posiedzenia Senatu UŚ, 16 XII 1980, AUŚ, Protokoły Senatu UŚ 1980, 139/5, k. 3; „Non omnis moriar”, 49, 231, 268. 
na czele Instytutu stali: Zieliński (od 1 października 1971 do 30 września 1972), Stefan M. Kuczyński (od 1 października 1972 do 30 września 1974), Chlebowczyk (od 1 października 1974 do 30 września 1976), Wacław Długoborski (od 1 października 1976 do 30 sierpnia 1978) i Rechowicz (od 1 września 1978 do 1 października 1980).

Istotną cezurą w dziejach IH UŚ pozostaje okres „karnawału Solidarności”. Ożywienie polityczne przełomu lat siedemdziesiątych i osiemdziesiątych XX w. przyniosło również aktywizację instytutowej społeczności: we wrześniu $1980 \mathrm{r}$. jedna z pierwszych na uczelni grupa Niezależnego Samorządnego Związku Zawodowego „Solidarność” została zarejestrowana właśnie na Wydziale Nauk Społecznych (działała przy Międzyzakładowym Komitecie Robotniczym „Huty Katowice”, reprezentantem historyków we władzach był Marek Nita). W listopadzie tego samego roku na Wydziale Nauk Społecznych powstało Niezależne Zrzeszenie Studentów, z silnym udziałem studentów IH. Mimo posiadanej „łatki” jednego z bardziej zideologizowanych wydziałów „czerwonego” Uniwersytetu, historycy UŚ weszli w skład wielu „odwilżowych” formacji, przede wszystkim aktywnie współtworząc Wszechnicę Górnośląską - podmiot zajmujący się upowszechnianiem efektów badań naukowych bez narzucanych dotąd przez władze ograniczeń cenzorskich. Wśród członków i konsultantów Rady znaleźli się m.in. Barciak, Gruchała oraz Fertacz ${ }^{16}$.

Warto wskazać także, że wydarzenia sierpnia 1980 r. przyniosły zmiany na szczeblach władz UŚ: odsunięcie z funkcji rektora Rechowicza ${ }^{17}$. Ważnym także dla studentów historii aspektem sierpnia 1980 r. był szeroki dostęp do trudno dotychczas dostępnej literatury zagranicznej i wydawnictw drugiego obiegu. W wyniku wprowadzenia stanu wojennego zostało aresztowanych $\mathrm{i}$ internowanych kilkudziesięciu studentów i pracowników UŚ (wśród nich studenci IH: Tomasz Jankowski, Jan Jurkiewicz, Maciej Klich, Piotr Lazar, Jędrzej Lipski i Zbigniew Skurzok) ${ }^{18}$. Podobnie jak w całej uczelni, również IH został poddany procesowi weryfikacji pracowników pod względem politycznym. Skutkiem przeobrażeń dekady lat osiemdziesiątych była stagnacja widoczna także w działalności Instytutu. Osłabła działalność badawcza pracowników, zahamowane zostały też ich awanse naukowe. Dodatkowym powodem pogorszenia sytuacji Instytutu była nagła śmierć Chlebowczyka i Michalkiewicza (obaj zmarli w 1985 r.) ${ }^{19}$. Doraźnie korzystano ze wsparcia historyków z innych części Polski (w semestrze letnim 1984 r. w Instytucie pracował np. mediewista Jacek Wiesiołowski z IH PAN w Warszawie).

16 Por. Tomasz Kurpierz, Zbuntowani. Niezależne Zrzeszenie Studentów w województwie katowickim 1980-1989 (Katowice: Instytut Pamięci Narodowej - Komisja Ścigania Zbrodni przeciwko Narodowi Polskiemu, Oddział w Katowicach, 2013); idem, „Strajki i inne formy oporu studenckiego na katowickich uczelniach w latach 1980-1989", w Katowice w 143. rocznice uzyskania praw miejskich..., 168-195; Jacek Siebel, 40 lat Uniwersytetu Ślaskiego. Szkic z dziejów. Przewodnik po wystawie (Katowice: Muzeum Historii Katowic, 2008), 32-35.

17 Por. Fic, „Wielki wybitny historyk śląski”, 217.

18 „Wyrósł $z$ dobrego drzewa”, 165-168.

19 Nowak, „Życiorys Profesora”, 11; „Non omnis moriar”, 230. 
Jednak to właśnie w latach osiemdziesiątych w IH pojawiła się generacja nowych badaczy-wykładowców, którzy odtąd stanowili o sile katowickiego ośrodka (wśród nich m.in.: badacz pradziejów Piotr Boroń, mediewista Jerzy Sperka, zajmujący się nowożytnością Dariusz Nawrot oraz historycy XX w.: Zbigniew Hojka, Joanna Januszewska-Jurkiewicz, Ryszard Kaczmarek, Kazimierz Miroszewski i Krzysztof Nowak). W omawianym okresie na czele Instytutu stali: Kunisz (od 1 października 1980 do 31 sierpnia 1984), Michalkiewicz (od 1 września 1984 do 7 grudnia 1985) i Szydłowski (od 1 lutego 1986 do 31 sierpnia 1990).

\section{$\mathrm{W}$ realiach III RP}

Transformacja systemowa 1989 r. spowodowała znaczące zmiany w niemal wszystkich sferach życia, w tym także w zakresie szkolnictwa wyższego ${ }^{20}$. Postępujący proces tzw. skolaryzacji przyniósł niespotykany dotąd wzrost liczby studentów historii, wymuszając niejako rozwój struktury UŚ, a w jego strukturach także IH. Przełom wieków przyniósł także wymuszoną demograficznie zmianę pokoleniową. W 1997 r. zmarł prof. Szydłowski, rok później prof. Kunisz; cześć pracowników osiągnęła wiek emerytalny, z kilkoma osobami rozwiązano umowę, gdy w wyznaczonym terminie nie uzyskali awansu naukowego. Na przełomie wieków XX i XXI w IH wykrystalizowała się struktura, obejmująca dziewięć zakładów: Historii Starożytnej; Historii Średniowiecznej; Historii Nowożytnej XVI-XVIII wieku; Historii Nowożytnej XIX wieku; Historii Najnowszej 1918-1945; Historii Najnowszej po 1945; Nauk Pomocniczych Historii; Metodologii i Dydaktyki Historii oraz Archiwistyki i Historii Śląska. W miejsce uczonych często pracujących niemal od początku istnienia Instytutu pojawiali się kolejni badacze (w grupie, która zasiliła IH w ostatniej dekadzie XX w. znaleźli się m.in.: historyk starożytności Agata Kluczek, badacze średniowiecza Idzi Panic i Bożena Czwojdrak, zajmujący się badaniem okresu nowożytnego Jan Kwak, Dariusz Rolnik oraz Aleksandra Skrzypietz, prawnik oraz historyk XX w. Lech Krzyżanowski, historyk XX w. i archiwista Edward Długajczyk, historyk XX w. i dydaktyk historii Maciej Fic oraz metodolog Tomasz Pawelec). Dołączyli do nich zatrudnieni już w XXI w. kolejni naukowcy (m.in. mediewista Jakub Morawiec, archiwista i badacz nowożytności Wacław Gojniczek, metodolog i historyk wieków XIX-XX Dorota Malczewska-Pawelec, historyk XX w. Miłosz Skrzypek, politolog i historyk XX w. Jarosław Tomasiewicz czy nowożytnik Ryszard Skowron), powodując, że kadrę naukowo-badawczą IH należy uznać za jedną z najsilniejszych $\mathrm{w}$ jego historii.

Według stanu z 2018 r. kadra naukowo-dydaktyczna Instytutu liczy 45 osób: 25 samodzielnych pracowników nauki (siedmiu profesorów tytularnych i 17 doktorów

20 Por. Andrzej Chwalba, III Rzeczpospolita. Raport specjalny (Kraków: Wydawnictwo Literackie, 2005), 149-150. 
habilitowanych), 17 doktorów i czworo magistrów. Jej trzon stanowią aktualnie absolwenci IH UŚ, ale wśród pracowników są także byli studenci UJ, Uniwersytetu im. Adama Mickiewicza w Poznaniu, Uniwersytetu Wrocławskiego czy Uniwersytetu im. Marii Curie-Skłodowskiej w Lublinie. Do silnych stron IH należy zaliczyć także bez wątpienia zainicjowanie dwóch serii czasopism parametryzowanych (od 1999 r. rocznika „Średniowiecze Polski i Powszechne”, a od 2000 rocznika „Wieków Starych i Nowych”), a także współpracę w publikowaniu międzynarodowego półrocznika „Insterstitio-East European Review of Historical and Cultural Anthropology” (wydawanego przez Institute of Social History „ProMemoria” Moldova State University) czy „Śląskiego Almanachu Powstańczego” (wydawanego we współpracy z Muzeum Powstań Śląskich w Świętochłowicach). Pracownicy Instytutu zasilają znaczące ogólnopolskie gremia (Sperka jest członkiem Rady Narodowego Programu Rozwoju Humanistyki przy Ministerstwie Nauki i Szkolnictwa Wyższego, Miroszewski należy do zespołu ekspertów Polskiej Komisji Akredytacyjnej), pełnią ważne funkcje w strukturach regionalnych (Kaczmarek kieruje Instytutem Badań Regionalnych przy Bibliotece Śląskiej w Katowicach, a Nawrot Instytutem Zagłębiowskim), zwyciężają w konkursach (tylko w 2017 r. laureatami konkursów NPRH zostali Kaczmarek, Pawelec, Skowron i Mirosław Węcki; w projektach Narodowego Centrum Nauki udział bierze Rolnik i Morawiec, natomiast w projekcie realizowanym w ramach programu Horyzont 2020 Kaczmarek oraz Lisa Heberkern).

Ostatnie lata stały się okresem, w którym IH włączył się w proces reorganizacji szkolnictwa wyższego. W ramach realizacji tzw. edukacji promienistej do $2013 \mathrm{r}$. studia historyczne prowadzone były także w uruchomionym w 2001 r. Ośrodku Dydaktycznym UŚ w Rybniku. Od roku 2005 dotychczasową formułę jednolitych pięcioletnich studiów magisterskich zastąpiły wprowadzone w ramach tzw. systemu bolońskiego trzyletnie studia licencjackie oraz dwuletnie studia magisterskie ${ }^{21}$. Odpowiadając na zapotrzebowania rynku pracy, od 2013 r. IH rozpoczął także studia na nowym kierunku - Turystyce historycznej. Społeczność IH systematycznie stara się odpowiadać na wyzwania współczesności - zarówno poprzez udoskonalanie swojej oferty edukacyjnej (od roku akademickiego 2016/2017 prowadzi wspólnie z Wydziałem Nauk o Ziemi międzyobszarowe magisterskie studia z Turystyki, od 2017 r. rozpoczęto także międzynarodowe Środkowoeuropejskie Studia Historyczne, realizowane razem ze słowackim Uniwersytetem im. Mateja Bela w Bańskiej Bystrzycy i czeskim Uniwersytetem Ostrawskim). Ofertę edukacyjną dopełnia propozycja studiów podyplomowych. Rokrocznie prowadzone są Podyplomowe Kwalifikacyjne Studia Historyczne, cyklicznie podejmowane są inicjatywy

${ }^{21}$ W roku akademickim 2018/2019 oferta historycznych studiów I i II stopnia obejmowała cztery specjalności: administracyjno-samorządową, archiwalną i zarządzania dokumentacją, nauczycielską i muzealną. Studia I stopnia były prowadzone zarówno w formie stacjonarnej, jak i niestacjonarnej. 
przedsięwzięć współfinansowanych przez Europejski Fundusz Społeczny (w latach 2007-2008 Podyplomowych Studiów w zakresie ICT, języka obcego oraz wiedzy o społeczeństwie oraz Podyplomowych Studiów w zakresie ICT, języka obcego oraz historii; w latach 2011-2013 Podyplomowych Studiów w zakresie ICT, języka obcego oraz historii i społeczeństwa. Dziedzictwa epok).

Obecnie, w ramach Instytutu Historii funkcjonuje osiem zakładów: Historii Starożytnej (kierownikiem jest Kaczanowicz); Historii Średniowiecznej i Nauk Pomocniczych Historii (kierowany przez Panica); Historii Nowożytnej XVI-XVIII wieku (pod kierownictwem Skowrona); Historii Nowożytnej XIX wieku (na czele zakładu stoi Nawrot); Historii Najnowszej 1918-1945 (kierownikiem jest Fertacz); Historii Najnowszej po 1945 (kierowany przez Nowaka); Metodologii, Dydaktyki i Kultury Historycznej (kierownikiem jest Pawelec) oraz Archiwistyki i Historii Śląska (pod kierownictwem Kaczmarka) ${ }^{22}$. Aktualna struktura organizacyjna IH oraz zatrudnieni pracownicy pozwalają na prowadzenie badań naukowych we wszystkich epokach historycznych, gwarantując jednocześnie właściwy poziom edukacji. Historycy UŚ są autorami licznych i znaczących prac naukowych, także nagradzanych przez liczące się środowiskowe gremia (tylko w latach 2015-2017 Januszewska-Jurkiewicz, Nowak i Panic otrzymali nagrody im. Wacława Felczaka i Henryka Wereszyckiego, Nawrot zdobył „Złotą Pszczołę”, Katarzyna Niemczyk otrzymała nagrodę im. Adama Heymowskiego, Barbara Kalinowska-Wójcik „Górnośląskiego Tacyta”, Katarzyna Wilczok nagrodę IPN za Najlepszy Debiut Książkowy, a Ryszard Kaczmarek Nagrodę Literacką i Historyczną „Identitas”). Pracownicy IH wchodzą także w skład rad naukowych oraz redakcji m.in. czasopism: „Acta historia Neosoliensia”; „Documenta Lichtensteina. Series Nova”; „Slezský Sborník”; „Paginae historae. Sborník Národního archivu”; „Res Historica”; „Sarmatia Europaea. Polish Review of Early Modern History” czy „Szkiców Archiwalno-Historycznych”.

Katowiccy historycy angażują się także w działalność organizacyjną UŚ - na przestrzeni lat we władzach dziekańskich WNS (wcześniej Wydziału Humanistycznego) zasiadali m.in.: Zieliński (od 2 stycznia 1971 do 30 sierpnia 1972), Kunisz (od 1 stycznia 1971 do 30 września 1972), Długoborski (od 1 października 1972 do 1 października 1976), Szydłowski (od 1 stycznia do 31 sierpnia 1981 i w latach 1982-1984), Topol (od 1 listopada 1979 do 31 grudnia 1980), Salamon (od 1 września 1980 do 31 sierpnia 1981), Paździora (od 1 września 1987 do 31 sierpnia 1990), Wanatowicz (od 1 września 1987 do 31 sierpnia 1990), Zbigniew Kiereś (od 1 września 1993 do 31 sierpnia 1996), Kaczmarek (od 1 września 2002 do 31 sierpnia 2008), Kaczanowicz (od 1 września 1990 do 31 sierpnia 1993 oraz od 1 września 2008 do 31 sierpnia 2016) i Miroszewski (od 1 września 2012); kierownikami albo prodziekanami Studium dla Pracujących/ds. Studiów Zaocznych byli ponadto Żerdziński (1 września 1975 do 31 sierpnia 1976), Molenda (od 1 września do 31 października 1976), Paździora (od 1 stycznia 1977 do 30 września 1987) i Miroszewski

22 Por. Wydział Nauk Społecznych. Uniwersytet Śląski [folder informacyjny], Katowice, 2017, 12. 
(od 1 września 1996 do 31 sierpnia 2012) 23. Po 1989 r. dyrektorami IH byli: Szydłowski (od 1 września 1990 do 31 sierpnia 1993), ponownie Kunisz (od 1 września 1993 do 31 listopada 1998), Panic (najpierw od 1 grudnia 1998 do 31 sierpnia 1999 jako pełniący obowiązki, a następnie od 1 września 1999 do 31 sierpnia 2002 jako dyrektor), Wanatowicz (od 1 września 2002 do 31 sierpnia 2008), Kaczmarek (od 1 września 2008 do 31 sierpnia 2012) i Sperka (od 1 września 2012).

\section{Maciej Fic}

Half of the century of historical education at the University of Silesia in Katowice. From the history of the Institute of History, University of Silesia (1969-2019)

\section{Summary}

The text is dedicated to the Institute of History at the University of Silesia. It describes a half of the century of its existence in a very synthetic way. It shows its origins reaching the time when the Departament of History of High Pedagogical School (1957-1968) and the Team Departament of History of the University of Silesia (1968-1969) functioned. It also introduces the next stages of Institute activity: since the time it was created in 1969, through the realities of two decades of People's Republic of Poland (1970's, and 1980's) and "the new beginning" at the time of birth of III Republic of Poland, until the contemporary times (2018). The text attempts to distinguish internal censorship, deals with the changing personnel situation, research activity and the presence of representatives of History Institute on the Polish Historical research ground.

${ }^{23}$ Por. „Wyrósł z dobrego drzewa”, 85, 107-109; „Mądrość zbudowała sobie dom...”, 455, 459, 463,468 . 